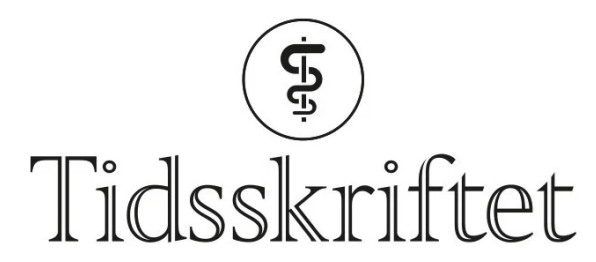

DEN NORSKE LEGEFORENING

\title{
Klinisk relevant om psykologi for leger
}

ANMELDELSER

TUVA KOLSTAD HERTZBERG

Fastlege, Østensjø legesenter

Oslo

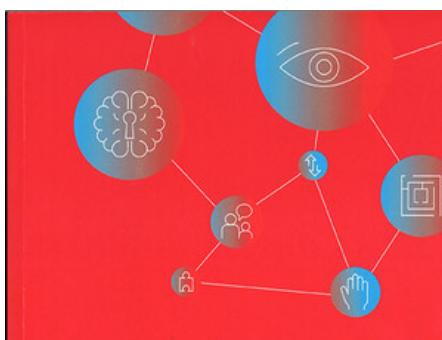

Psykologi i

medicinsk

praksis

Malene Flensborg Damholdt, Mimi Yung Mehlsen

Psykologi i medicinsk praksis

364 s, tab, ill. København: FADL's forlag, 2020. Pris DKK 300

ISBN 978-87-93590-86-1

Denne boka er ment å være en praksisnær og anvendelig lærebok i psykologi for yngre leger og medisinstudenter. Ambisjonen er å favne hele mennesket i den tiden vi lever $\mathrm{i}$. Dette forklarer den store spredningen i temaene. Temaene belyses fra et psykologisk perspektiv, og de har til hensikt å gi leseren klinisk anvendelig evidensbasert kunnskap, $\mathrm{i}$ tillegg til å innby til teoretisk og personlig refleksjon. Bokas forfattere er forskere som har klinisk erfaring innenfor de områder de beskriver. 
Boken er skrevet på dansk og har 22 enkeltkapitler som er skrevet av ulike forfattere. Kapitlene har en gjennomgående lik struktur, noe som gjør at boken fremstår helhetlig til tross for et vidt spenn av temaer.

Alle kapitlene starter med hovedpunkter. Bokser med spørsmål ment for teoretisk og personlig refleksjon, illustrerende kasuser og figurer bidrar til en ryddig og oversiktlig fremstilling, som enkelt kan brukes i den kliniske hverdagen.

Boken har dagsaktuelle temaer. For eksempel skisseres utfordringer knyttet til hvordan sosiale medier og ulike helseapper påvirker legerollen i møte med den moderne pasienten. Forfatterne foreslår hvordan legen kan kommunisere med pasientene om fornuftig bruk av ulike nettsider og helseapper. Jeg vil også trekke fram temaet tverrkulturell pasientkommunikasjon som nyttig og interessant. Enkelte kasuser er litt lange, og noen refleksjonsbokser kunne vært mer spesifikke.

Temaene i boken belyser legens rolle gjennom pasientens ulike utfordringer i livet. Boken byr på konkrete råd knyttet til kommunikasjon i krevende pasientkonsultasjoner. Den gir veiledning og verktøy til å håndtere utredning og behandling av pasienter med spesielt krevende problemstillinger, som for eksempel kroniske smerter. Jeg savner et kapittel om kommunikasjon med ungdom.

Jeg vil anbefale boka som en god grunnbok som inspirer til videre lesning innen de ulike temaene. Den gir både leger og legestudenter et innblikk i klinisk relevante psykologiske faktorer og teorier som er viktig hvis man skal mestre en helhetlig tilnærming til pasienten i praksis. Boken kan leses flere ganger og brukes som oppslagsverk, noe som gjør den relevant for erfarne leger også. Det hadde selvfølgelig vært en fordel om den ble oversatt til norsk.

Publisert: 22. februar 2021. Tidsskr Nor Legeforen. DOI:10.4045/tidsskr.20.0841

(C) Tidsskrift for Den norske legeforening 2023. Lastet ned fra tidsskriftet.no 26. april 2023. 